\title{
Dietary intake and health effects of selected toxic elements
}

\author{
André Luiz Oliveira da Silva, Paulo R.G. Barrocas, Silvana do Couto Jacob and Josino Costa Moreira*
}

Fundação Oswaldo Cruz, Avenida Brasil 4365, CEP 210410-210, Rio de Janeiro, RJ, Brazil; Corresponding author: josinocm@fiocruz.br

Anthropogenic activities have being contributing to the spread of toxic chemicals into the environment, including several toxic metals and metalloids, increasing the levels of human exposure to many of them. Contaminated food is an important route of human exposure and may represent a serious threat to human health. This mini review covers the health effects caused by toxic metals, especially $\mathrm{Cd}, \mathrm{Hg}, \mathrm{Pb}$ and $\mathrm{As}$, the most relevant toxic elements from a human health point of view.

Key words: bioavailability, contamination, heavy metals, metal toxicity.

Ingestão alimentar e efeitos sobre a saúde de alguns elementos químicos tóxicos: As atividades antrópicas têm contribuído para a introdução e dispersão de várias substâncias químicas no ambiente, incluindo metais e metaloides tóxicos, aumentando os níveis de exposição humana a eles. Alimentos contaminados constituem uma importante via de contaminação humana e podem representar sérios riscos à saúde. Esta revisão discute a absorção e os efeitos de alguns elementos químicos tóxicos, especificamente $\mathrm{Cd}, \mathrm{Hg}, \mathrm{Pb}$ e As, sobre a saúde humana.

Palavras-chave: biodisponibidade, contaminação, metais pesados, toxicidade.

\section{INTRODUCTION}

It is well known that only a few chemical elements (less than thirty) are consistently found in living organisms taking part in vital biochemical and physiological functions, and recognized as essential for life. Those required in concentrations higher than several hundred milligrams per day, form the main electrolytes and take part in the maintenance of the homeostasis and/or body structure. Essential trace elements (required from a few micrograms to a few milligrams per day) participate in innumerous biochemical vital processes necessary to maintain good health. Meanwhile, the majority of the known metals and metalloids are very toxic to living organisms and even those considered as essential, can be toxic if present in excess. In the last decades, the natural environmental concentrations of several chemical elements (toxic and essential) have been largely increased, mostly as a result of anthropogenic activities. They can impair important biochemical systems, constituting an important threat for the health of plants and animalsystems animal systems (Michalke, 2003). An overview of the environmental and biological fate of chemicals by living organisms is presented in Figure 1.
The adverse health effects of several chemical elements have been documented throughout history: Greek and Roman physicians were able to recognize symptoms of acute lead and arsenic poisoning long before toxicology became a science. Currently, the advances of toxicology has improved our knowledge about human exposure to toxic elements (metals and metalloids) and their health effects, such as developmental retardation, several types of cancer, kidney damage, endocrine disruption, immunological disorders (autoimmunity) and even death (Moreira and Moreira, 2004).

\section{Bioavailability and distribution}

The uptake of chemical elements by living organisms is a dynamic and complex process. Plants and animals absorb these elements from soils, sediments, and water by contact with their external surfaces, through ingestion and also from inhalation of airborne particles and vaporized metals. In general, more than one exposure route is involved in elemental intake.

The assimilation of an element (i.e., the bioavailable fraction) depends on a number of chemical and physico-chemi- 


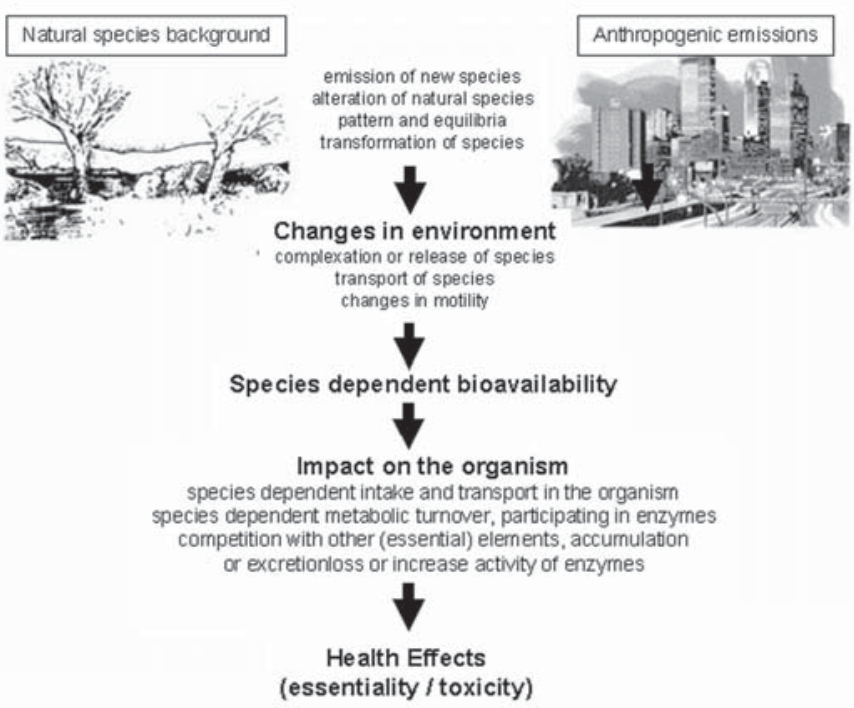

Figure 1. Natural and anthropogenic sources, cycling and fate of inorganic elements (Adapted from Michalke, 2003).

cal factors such as chemical speciation, solubility in organic medium, $\mathrm{pH}$, Eh, etc.

In soils, metals and metalloids can occur in both solid and aqueous (i.e., soil solution) phases. In solution, these elements can exist either as free ions or as various complexes associated with organic or inorganic ligands or as suspended colloidal particles. In the solid phase, they either can be adsorbed or absorbed on organic and inorganic soil components, exist as minerals or co-precipitated with other minerals. In general, ions in solution are more available for plant (and animal) uptake, immediately entering the food chain. However, metal ions present in the solid phase may become available under certain biological and physicochemical conditions such as, exudation of special chelators, desorption, redox and $\mathrm{pH}$ changes, etc.

Significant contamination of seeds, plants, and plant products with toxic chemical elements due to contaminated soil and water has been observed as result of release of these toxicants into the sea, rivers, lakes, or even into irrigation channels (Millis et al., 2004). Afterwards, the consumption of contaminated vegetables constitutes an important route of animal exposure.

Animals are exposed to these toxicants through a number of routes. The most important routes of contamination are respiratory, mostly for gaseous and particulate matters, dermal, for chemicals able to cross the skin barrier, and digestive, for food contaminants.

Absorption of metals and metal compounds inhaled as particles is influenced by several processes that includes deposition, mucociliary and alveolar clearance, solubilization and chemical binding. After entering the body the metal deposited in nasopharyngeal, tracheobronchial, or pulmonary compartments may be transported by mucociliary action to the gastrointestinal tract. Metals can also be phagocyted by macrophages.

Probably, food is the most important route for accumulating most chemical elements (essential and toxic). Certain elements, such as mercury, present in organisms of lower trophic levels can be efficiently transferred to higher-level organisms, becoming more concentrated at the top of the food chain (biomagnification).

The dietary contribution for toxic metal intake has been extensively studied (FSIS 48/04, 2000; Santos et al., 2004). An estimated dietary intake of $\mathrm{Pb}, \mathrm{Cd}$ and $\mathrm{Hg}$ from the total diet, in some selected countries, is presented in table 1 . These results clearly show the importance of socio-economic and cultural factors on the dietary intake of these toxic metals.

Furthermore, this study has confirmed the importance of vegetables and cereals as significant sources for the dietary intake of these toxic metals (table 2). In addition, some important food sources of the most relevant toxic elements are shown in table 3 .

In general, an equilibrated diet can provide all necessary elements for the body functions. Low intake of a given element can be a result of low dietary intake, poor bioavailability and the presence of antagonists in the diet. The chemical form of an element in the diet is a major factor of metal deficiency and/or toxicity. It is important to note that determining total concentration of a chemical element cannot provide the required information for a correct evaluation of its mobility, bioavailability or impact on ecological systems or biological organisms. The knowledge of the chemical speciation is fundamental for understanding the chemical and biochemical behavior of an element and its toxicity.

Table 1. Estimated intake of dietary toxic metals ( $\mu$ g.person ${ }^{-1}$.day $\left.^{-1}\right)$ from total diet (Adapted from Chen and Gao, 1993)

\begin{tabular}{cccc}
\hline Country (year) & $\mathrm{Pb}$ & $\mathrm{Cd}$ & $\mathrm{Hg}$ \\
\hline China (1990) & 86.3 & 13.8 & 10.3 \\
Japan (1988) & 85.0 & 29.0 & - \\
USA (1988) & 9.80 & 13.0 & 3.2 \\
UK (1988) & 60.5 & 18.9 & - \\
Sweden (1988) & 17.0 & 12.0 & 1.80 \\
Guatemala (1986) & 254 & 29.0 & 10.8 \\
Global (1991) & 153 & 25.0 & - \\
\hline
\end{tabular}


Table 2. Contribution (\% of daily intake) of various food groups to dietary intakes of $\mathrm{Pb}, \mathrm{Cd}$ and $\mathrm{Hg}$ (Adapted from Chen and Gao, 1993).

\begin{tabular}{lcccccccc}
\hline Metal & Cereals & $\begin{array}{c}\text { Legumes and } \\
\text { nuts }\end{array}$ & Meats & Eggs & Milk & Vegetables & Fruits & $\begin{array}{c}\text { Aquatic } \\
\text { foods }\end{array}$ \\
\hline $\mathrm{Pb}$ & 39.6 & 4.4 & 5.6 & 5.1 & 0.3 & 27.5 & 5.4 & 2.8 \\
$\mathrm{Cd}$ & 54.3 & 4.3 & 5.8 & 0.7 & 0.7 & 23.9 & 2.9 & 3.6 \\
$\mathrm{Hg}$ & 0.4 & 3.9 & 5.8 & 5.8 & - & 8.7 & 5.8 & 9.7 \\
\hline
\end{tabular}

Table 3. Some possible food sources of the toxic chemical elements

\begin{tabular}{|l|l|}
\hline Contaminant & Possible food sources \\
\hline Cadmium & $\begin{array}{l}\text { Peanuts, soybeans, rice, medicinal herbs, water spinach, pig, duck liver paste, wine, beer, lettuce, corn, oats, } \\
\text { wheat, spinach, culinary herbs, sunflower kernels, milk, cheese, eggs, fish, shrimp, oysters, mushroom, garlic }\end{array}$ \\
\hline Arsenic & $\begin{array}{l}\text { Carrots, lettuce, beetroots, moonshine, honey, smoked food, wine, beer, milk, mustard, wheat, mineral salt to } \\
\text { beef cattle, eggs, cocoa powder, poultry, breast milk, tamarind candy, some folk remedies, buckwheat, raisins, } \\
\text { calcium supplements, rice, potato, paprika powder, mussels }\end{array}$ \\
\hline Mercury & $\begin{array}{l}\text { Bovine and chicken meat, green papaya, rice, sheep, algae products, seafood, Indian mustard, tomato, flour, } \\
\text { grape juice, cooked spinach, carrots, shrimp, wine, milk, soy-sauce }\end{array}$ \\
\hline
\end{tabular}

Sources: Schoof et al. (1999), Jarup (2003), Dorea (2004), Satarug and Moore (2004)

The relevance of such an approach for health has been discussed elsewhere (Apostoli, 1999, 2002). A summary of the most important chemical forms of $\mathrm{As}, \mathrm{Pb} . \mathrm{Cd}$ and $\mathrm{Hg}$ and their toxicities is presented in table 4. In practice, chemical speciation analysis in environmental and biological samples is not an easy task. Whether different species can be grouped or should be classified separately, will depend on the relevance of the species differences in relation to the health damage caused by toxic elements. Thus, chemical speciation analysis is an essential tool for useful risk assessments of elements in the environment, leading to more effective diagnosis and therapy of trace element depletion or toxicity, and better health.

Chemical elements present as free ions and those readily ionized are almost completely absorbed by the body. Transition metals readily form stable covalent complexes and usually interact as parts of macromolecules (proteins, enzymes, hormones, etc.) according to their chemical characteristics including oxidation state (IEH, 1998; Schoof, 2003a,b).

This tendency ensures that these metals, in vivo, are complexed with particular biological groups, such as sulfhydryl $(-\mathrm{SH})$, amino $(-\mathrm{NH})$, hydroxyl $(-\mathrm{OH})$, disulfide $(-\mathrm{SS})$, and carboxylic $(-\mathrm{COOH})$ groups of amino acids, peptides, proteins, phospholipids, citrate, ascorbate, and other tissue constituents. These groups are also found in
Table 4. Chemical forms and toxicity of $\mathrm{As}, \mathrm{Cd}, \mathrm{Pb}$ and $\mathrm{Hg}$.

\begin{tabular}{|l|l|}
\hline Element & Toxicity comment \\
\hline Arsenic & $\begin{array}{l}\text { As(III) and As(V) are toxic; organoarsenical species } \\
\text { show decreased toxicity, whereas arsenobetaine and } \\
\text { arsenocholine are not toxic. }\end{array}$ \\
\hline Mercury & $\begin{array}{l}\text { Hg species are generally toxic, but, inorganic Hg salts } \\
\text { are less dangerous than methylated forms. The latter } \\
\text { are considerable more toxic (by a factor of 100) and } \\
\text { can be enriched up to 10,000-fold in fish }\end{array}$ \\
\hline Lead & $\begin{array}{l}\text { Pb species are generally toxic, however, organic } \\
\text { lead species are more easily absorbed by the } \\
\text { gastrointestinal tract than inorganic species }\end{array}$ \\
\hline Cadmium & All species are very toxic. All of them need attention \\
\hline
\end{tabular}

Sources: ATSDR (1999), ATSDR (2000), Michalke (2003)

important biomolecules with catalytic, structural or transport functions. Each transition metal possesses its affinity for organic binding. In general; elevated values for equilibrium constant are observed for biomolecules rich in - $\mathrm{SH}$ groups, towards which metals such as $\mathrm{Pb}$, As and $\mathrm{Hg}$ show particular reactivity. Proteins, such as metallothioneins, ferritin, transferrin, lactoferrin, melanotransferrin, hemosiderin, ceruloplasmin and amino acids (glutathione (GSH), cysteine, histidine and others) are examples of biomolecules able to bind toxic metals in biological matrixes. The reactivity for 
a wide range of biological ligands lies at the basis of the damaging action of the metal ion at the molecular level, and determines the characteristic toxicity of the absorbed metal. The knowledge of mechanisms of action is relevant for identifying possible targets and possible related biomarkers of effects. Health effects induced by toxic metals vary greatly; from irritant and acute or chronic systemic toxic effects to teratogenic, mutagenic and carcinogenic effects.

The reactive elements occurring in food, mostly as organic complexes or associated to with fibers, often have a low solubility within the intestinal lumen and are frequently poorly absorbed. Absorption of these minerals would benefit from lower concentrations or absence of agents such as phytates, oxalates and also of fiber in the diet (Hazell et al., 1985).

Additionally, the effect of other micronutrients on metal absorption/toxicity is also important. Micronutrients can interact with toxic metals at several points in the body: absorption and excretion of toxic metals; transport of metals in the body; binding to target proteins; metabolism and sequestration of toxic metals; and finally, in secondary mechanisms of toxicity such as oxidative stress. Therefore, a diet poor in micronutrients can have an important influence on the toxicity of nonessential metals such as $\mathrm{Cd}, \mathrm{Pb}, \mathrm{Hg}$ and As. Excellent reviews on these subjects are available (Hurrell, 2001; Peraza et al., 1998)

The gastrointestinal absorption of inorganic salts is dependent of a number of factors such as presence of transport systems, particle size, solubility, dose, simultaneous administration of other substances, $\mathrm{pH}$, rate of transit and host factors such as species, age, nutritional status and sex. It can vary from less than $10 \%$ for $\mathrm{Pb}, \mathrm{Cd}, \mathrm{In}, \mathrm{Sn}, \mathrm{U}$ to almost complete absorption (90-100\%) for water-soluble inorganic salts of trivalent arsenic, germanium and thallium. Some complex interference in intestinal absorption of a given metal such as that observed by $\mathrm{Pb}$ in the presence of $\mathrm{Ca}, \mathrm{Zn}$ and Fe have been attributed to a competition for carrier proteins (Powell et al., 1999; Bressler et al., 2004).

In biological fluids and tissues, most metals and metalloids are not present as free cations. The blood level of elements is influenced by the level of current exposureabsorption, by their body burden and by excretion rate. In blood they are usually bound to red cells or to plasma proteins. Lead and cadmium are almost completely bound to red blood cells. The chemical elements bound to plasma proteins constitute the fraction available for transport into and out of the tissues. The passage of these elements from the blood into the interstitial fluid and intracellular compartment is fully dependent of on the diffusible fraction. The distribution of those metals present in the ionized and unbound form is directly related to the concentration gradient in the different compartments.

Albumin, a plasma protein, has a great capacity to bind several metals, yet, for some metals, binding occurs with proteins having a specific transport function such as transferring or ceruloplasmin. These bindings constitute a major protective mechanism against metal toxicity. Thus, the availability of toxic elements is regulated to a large extent by the availability and relative concentrations of these biological ligands as well as by the ability of the resulting metal complexes to serve as substrates for the various organic solute transporters (Powell et al., 1999; Bressler et al., 2004). Absorption and distribution mechanisms of chemical elements in an animal organism are presented in figure 2 .

The essential elements virtually do not produce toxic effects on human and animals as a result of the presence of homeostatic mechanisms (for example, the intestinal control of absorption). In fact, living organisms have evolved transport mechanisms for the active uptake and/or extrusion, enabling cells to regulate their intracellular concentrations Meanwhile, toxic elements can compete with the essential ones for protein binding sites and this is the underlying cause of the toxicity effects of many of them (IEH, 1998).

The toxic effects of metals and metalloids are partly due to the direct inhibition of enzymatic systems, and also to the indirect alteration of the essential metal-ion equilibrium. As a consequence their biological availability is inhibited and damage to the cell membrane can occur by the disruption of ion transport across it.

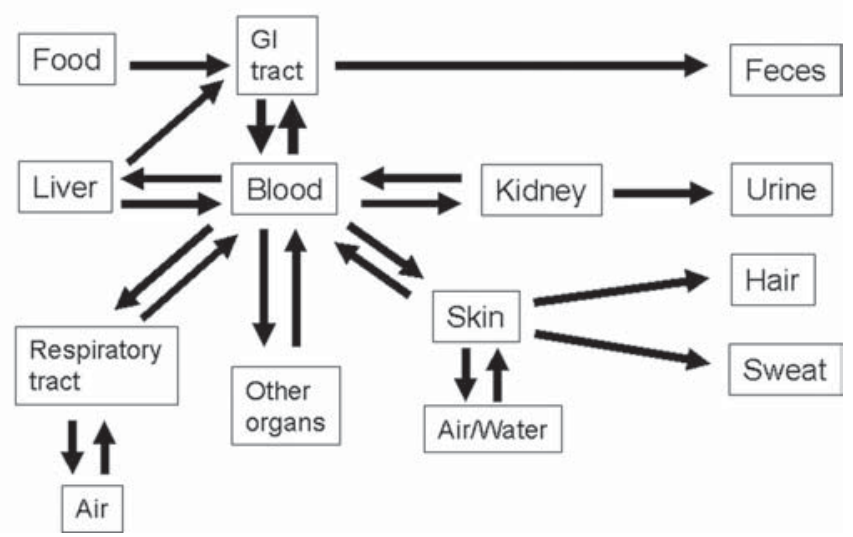

Figure 2. Absorption and distribution of inorganic chemical elements in animals (Adapted from Apostoli, 2002). 


\section{The tolerable daily intake approach}

In order to avoid undesirable health effects as resulted of "excessive" intake of toxicants (including toxic metals), international and national scientific organisms such as FAO/ WHO, FDA, European Union, etc have used the safety factor approach for establishing acceptable or tolerable intakes of substances that exhibit threshold toxicity. The acceptable daily intake (ADI) or tolerable daily intake (TDI) or provisional tolerable weekly intakes (PTWI) are used to describe "safe" levels of intake for several toxicants including toxic metals (Speijers, 1999; Herrman and Younes, 1999; Larsen and Richold, 1999; Kroes and Kozianowski, 2002).

For most kinds of toxicity, it is believed that there is a dose below which no adverse effect will occur. For chemicals that give rise to such toxic effects, a tolerable daily intake (TDI), i.e. an estimate of the amount of a substance in food, expressed on a body weight basis (mg.kg-1 or mg.kg-1 of body weight) that can be ingested over a lifetime without appreciable health risk, should be derived as follows:

TDI $=($ NOAEL or LOAEL $) /$ UF

where:

NOAEL $=$ no-observed-adverse-effect level;

LOAEL $=$ lowest-observed-adverse-effect level;

$\mathrm{UF}=$ uncertainty factor

The NOAEL is defined as the highest dose or concentration of a chemical in a single study, found by experiment or observation that causes no detectable adverse health effect. Wherever possible, the NOAEL is based on long-term studies, NOAELs obtained from short-term studies and studies using other sources of exposure (e.g. air) may also be used.

If a NOAEL is not available, a LOAEL may be used, which is the lowest observed dose or concentration of a substance at which there is a detectable adverse health effect. In these cases, an additional uncertainty factor is normally applied

The guideline value $(\mathrm{GV})$ can be derived from the TDI, as follows:

$\mathrm{GV}=(\mathrm{TDI} \mathrm{x}$ bw P) $/ \mathrm{C}$

Where: $\mathrm{bw}=$ body weight

$\mathrm{P}=$ fraction of the TDI allocated for that kind of food

$\mathrm{C}=$ daily consumption

Exposure exceeding the TDI value for short periods should not have deleterious effects upon health. However, acute effects may occur if the TDI is substantially exceeded even for short periods of time. Additionally, contaminants possessing very long half-lives can be accumulated in the body and chronic effects are most often observed when critical concentrations are reached in target tissues.

Once absorbed into the human body, the inorganic toxic elements may induce several deleterious effects varying from irritant to acute or chronic effects. In addition to these toxic effects, some authors describe another possible mode of action that is observed at low doses, named "hormesis". Hormesis is defined as the stimulatory action of low dose (sub-inhibitory amounts) of a toxicant and it has been reported for a large number of chemicals including inorganics (Calabrese and Baldwin, 2004).

A more detailed discussion of the health effects of As, Cd, $\mathrm{Pb}$ and $\mathrm{Hg}$ is presented below.

\section{Cadmium}

$\mathrm{Cd}$ is a nonessential element and all of its compounds are considered to be highly toxic to humans. $\mathrm{Cd}$ is used in several industrial processes such as protective coatings (often applied by electroplating) for some metals such as iron, preparation of Cd-Ni batteries, control rods and shields within nuclear reactors and television phosphors. Some compounds are used as stabilizers for PVC.

Food contamination is the most important pathway of $\mathrm{Cd}$ exposure to the general population, excluding smokers. $\mathrm{Cd}$ is more readily taken up by plants than other metals, such as lead. Factors contributing to the presence of $\mathrm{Cd}$ in the soil are fallout from the air, Cd-containing water used for irrigation, and $\mathrm{Cd}$ present in fertilizers (Smolders, 2001). Another concern as a potential source of $\mathrm{Cd}$ toxicity is the use of commercial sludge to fertilize agricultural fields (Reesal et al., 1987).

The concentration of $\mathrm{Cd}$ in foods is related to its level in the soil and its bioavailability. Crops cultivated in contaminated soil will present higher concentrations of $\mathrm{Cd}$ than those from uncontaminated ones. Plant-based foods grown in uncontaminated soils rarely exceed 0.2 mg. $\mathrm{kg}^{-1}$ of Cd calculated on a fresh weight basis. Some root crops (carrots and parsnip) and some leafy crops (lettuce and spinach) are able to accumulate more $\mathrm{Cd}$ than other plant foods. Basic staple foods such as rice and wheat can accumulate relatively high amounts of $\mathrm{Cd}$ when grown in contaminated soils.

Cd intestinal uptake by farm animals is low $(0.03-5 \%$ of total $\mathrm{Cd}$ ). Its absorption is influenced by different dietary factors such as calcium, protein and vitamin D contents. Deficiency of these factors may increase $\mathrm{Cd}$ absorption. 
Internal organs of mammals such as liver and kidneys may also contain high amounts of $\mathrm{Cd}$.

The dietary $\mathrm{Cd}$ absorption rate in humans has been estimated at $5 \%$ (WHO, 1989; IPCS, 1992) of its total intake. Acute toxicity caused by $\mathrm{Cd}$ contaminated food is very unusual but chronic exposure may be frequent. (Satarug et al., 2004).

The daily intake of $\mathrm{Cd}$ was estimated as $25-60 \mu \mathrm{g}$ for a $70 \mathrm{~kg}$ person from uncontaminated areas but values of 10 to $61 \mu$ g.day ${ }^{-1}$ have also been reported. The metal transporter protein Nramp2, known also as DMT1, seems to be involved in Cd absorption (Tallkvist et al., 2001). Increased expression of the intestinal DMT1 has been found in iron deficiency and hemochromatosis. Increased expression of this metal transporter protein DMT1, in general, would provide individuals with greater capacity to absorb $\mathrm{Fe}$ and possibly $\mathrm{Cd}$. This explains a 3.4-fold increase in $\mathrm{Cd}$ body burden in women with low Fe stores (Satarug et al., 2004) and in individuals with low body Fe stores (Olsson et al., 2002). Therefore, special attention should be given to ensure adequate $\mathrm{Fe}$ intakes to reduce $\mathrm{Cd}$ absorption, because iron deficiency is the most common nutritional disease in the world affecting around 2 billion people (Satarug and Moore, 2004).

$\mathrm{Cd}$ is a normal constituent of tobacco, because Nicotiana species is able to concentrate $\mathrm{Cd}$ independent of soil-Cd content. The $\mathrm{Cd}$ content in tobacco varies widely, but a typical range is $1-2 \mu \mathrm{g} . \mathrm{g}^{-1}$ dry weight, equivalent to $0.5-1$ $\mu$ g.cigarette ${ }^{-1}$. Cd oxide generated during the burning of cigarettes is highly bioavailable. Approximately $10 \%$ of the inhaled $\mathrm{Cd}$ oxide is deposited in lung tissues, and another $30-40 \%$ is absorbed into systemic blood circulation of smokers. Smokers have 4-5 times higher Cd levels in blood and 2-3 times greater amounts of $\mathrm{Cd}$ in their kidneys than do nonsmokers (Satarug and Moore, 2004).

Cd poisoning was first described in 1858 but the worst case of human contamination occurred in Toyama city, Japan, from 1939 to 1954, where about two hundred people suffered from a condition termed 'Itai-itai', literally, 'ouchouch' disease. Multiple fractures and severe pain in the legs and lower back affected mainly post-menopausal women; most members of the community showed abnormal levels of glucose, calcium, and amino acids in their urine. Although this collection of signs and symptoms was unusual and persistent, it took investigators 15 years to discover that itaiitai was caused by large amounts of $\mathrm{Cd}$ in the village's water supply; the inhabitants of the community had for years been consuming rice contaminated by the effluent of a lead-zinc mine upstream from their rice paddies (Oudeh et al., 2002).

\section{Health effects of oral cadmium chronic exposure}

$\mathrm{Cd}$ is a cumulative toxicant that affects kidneys, bone metabolism and the reproductive tract, and it is also carcinogenic and an endocrine disruptor. The kidney is the critical organ in humans and other mammals exposed for long periods to the relatively small amounts of $\mathrm{Cd}$ that might occur in foods (Satarug and Moore, 2004). Long-term exposure to $\mathrm{Cd}$ leads to several morphopathological changes in the kidneys.

The renal toxicity of $\mathrm{Cd}$ is reduced or abolished by increasing intakes of zinc, copper, and selenium. The preventive effects of pretreatment with zinc and copper have been suggested to be the result of increased production of metallothionein in the liver and renal cortex (Pizent et al., 2001). Some authors suggest a correlation between age and $\mathrm{Cd}$ concentration in age-dependent renal dysfunction. This fact can explain the increase of renal dysfunction and others alterations linked to age. (Wu et al., 2001).

Several epidemiological studies in human populations correlate the exposure to $\mathrm{Cd}$ with high blood pressure and cardiovascular disease (Telisman et al., 2001 ) The suggested mechanism for this pathology is the interference of $\mathrm{Cd}$ in the rennin, angiotensin and aldosterone system. Some papers report the calcium excretion increased by $\mathrm{Cd}$ exposure in animals and humans (Wu et al., 2001) exposed to contaminated rice. These findings suggest that $\mathrm{Cd}$ could promote skeletal demineralization, which may lead to increases in bone fragility and risk of fractures. The mechanism by which $\mathrm{Cd}$ induces bone damage is not clear. Some evidence support an interference with vitamin $\mathrm{D}$, resulting in reduced calcium absorption. $\mathrm{Cd}$ is more toxic to bone metabolism of women (Jarup, 2003). Recently, Takebayashi et al. (2003) reported a gene deletion in the mitochondrial DNA of proximal tubule cells of rats with chronic $\mathrm{Cd}$ intoxication which is believed to represent the first step for the pathogenesis of osteomalacia. $\mathrm{Cd}$ probably is not a neurotoxic agent, possibly because $\mathrm{Cd}$ does not cross the blood-brain barrier. (Bellinger et al., 2004). In animals Cd causes severe placetal damage, however in humans the data in not sufficient to substantiate this conclusion..

$\mathrm{Cd}$ and its compounds are currently classified by IARC as a Group 1 carcinogen for humans. Occupational human exposure has been correlated with lung cancer. Prostate and renal cancers have been related to environmental exposure to 
$\mathrm{Cd}$ although this relationship is not very strong. In animals, $\mathrm{Cd}$ effectively induces cancers at multiple sites and by various routes (Waalkes, 2003).

Exposure to $\mathrm{Cd}$ has been linked to a wide range of detrimental effects on mammalian reproduction. Intriguingly, depending on the identity of the steroidogenic tissue involved and the dosage used, it has been reported to either enhance or inhibit the biosynthesis of progesterone, a hormone that is inexorably linked to both normal ovarian cyclicity and the maintenance of pregnancy. Thus, $\mathrm{Cd}$ has been shown to exert significant effects on ovarian and reproductive tract morphology. Low doses were reported to stimulate ovarian luteal progesterone biosynthesis whereas high doses inhibited it. In addition, $\mathrm{Cd}$ exposure, during human pregnancy, led to reduced birth weights and premature birth (Henson and Chedrese, 2004). Wildlife is severally affected by $\mathrm{Cd}$ too. Special attention should be given to this health effect of $\mathrm{Cd}$ because the consequences in human and animal reproduction could be disastrous to survival.

\section{Lead}

$P b$ is known and used since ancient times (it was mentioned in Exodus). Romans have used $\mathrm{Pb}$ for plumbing in water supply systems. $\mathrm{Pb}$ is used in uncountable forms in the modern world. Some examples are: storage batteries, cable coverings, plumbing, ammunition, manufacture of tetraethyl $\mathrm{Pb}$, sound absorbers, radiation shields around X-ray equipment and nuclear reactors, paints, while the oxide is used in producing fine "crystal glass" and "flint glass" with a high refractive index for achromatic lenses, solder and insecticides.

The entry of $\mathrm{Pb}$ into the food chain is a major concern, since it can cause chronic health problems. Plants can absorb $\mathrm{Pb}$ from soils and from a $\mathrm{PbEt}_{4}$ traffic-induced contaminated atmosphere. In fact, this source was responsible for more than $90 \%$ of total $\mathrm{Pb}$ emissions into the atmosphere in congested urban areas. Pbed gasoline and traffic volume were strongly correlated with concentrations of $\mathrm{Pb}$ in various environmental media. Atmospheric and soil $\mathrm{Pb}$ can contaminate water and consequently enter the aquatic food chains (Kaste et al., 2003).

$\mathrm{Pb}$ may be ingested by eating or drinking contaminated food and also by swallowing large particles (diameter greater than $5 \mu \mathrm{m}$ ). Cosmetics (including lip balm) are also an important source of $\mathrm{Pb}$ contamination (Pirkle et al., 1998; ATSDR Lead, 1999; Miller et al., 2004). The amount of Pb absorbed depends on age and the extent to which $\mathrm{Pb}$ particles are dissolved in the stomach. Experiments using adult volunteers showed that, for those who had eaten recently, the level of $\mathrm{Pb}$ in the blood was of about $6 \%$ of the total amount ingested. In adults who had not eaten recently, about 60-80 $\%$ of the $\mathrm{Pb}$ is absorbed in the stomach. In general, children can absorb $\mathrm{Pb}$ more easily than adults. The proportion of $\mathrm{Pb}$ absorbed from the gastrointestinal tract is about $10 \%$ in adults, whereas levels of $40-50 \%$ have been reported for infants. Gastrointestinal absorption is highly dependent on dietary or nutritional factors: both milk and fasting enhance absorption. Diets with low levels of calcium, vitamin D and iron have been shown to increase $\mathrm{Pb}$ absorption in laboratory animals. The water solubility of the different $\mathrm{Pb}$ salts is an important determinant of the gastrointestinal absorption of $\mathrm{Pb}$, and hence its bioavailability. Skin is an important exposure route for $\mathrm{Pb}$ contamination but only in cases where $\mathrm{Pb}$ compounds can easily penetrate it (Pirkle et al., 1998; Miller et al., 2004)

$\mathrm{Pb}$ is a zootoxic metal and most people and animals receive the largest portion of their daily $\mathrm{Pb}$ intake via food. $\mathrm{Pb}$ can enters food during storage and manufacture, e.g. in canned food and in alcoholic drinks. The most important pathway whereby atmospheric $\mathrm{Pb}$ enters the food chain is thought to be direct foliar contamination of plants. This contamination depends on the level of atmospheric contamination and its fallout. Additionally, contaminated air deposition may raise the level of $\mathrm{Pb}$ in the soil, which over time can result in an increased uptake of $\mathrm{Pb}$ by plants (Air Quality Guidelines for Europe, 2000).

\section{Health effects of oral chronic exposure to lead}

Children under 6 years are especially susceptible to the adverse effects of $\mathrm{Pb}$ for several reasons. These include their behavioral characteristics (outdoor activity, less concern for hygienic conditions, hand-to-mouth activities), their higher disposition for lead absorption and the prevalence of nutritional deficiencies (e.g. iron and vitamin D) among children that enhance absorption of $\mathrm{Pb}$ from the gastrointestinal tract. As the blood-brain barrier is not yet fully developed in young children, hematological and neurological adverse effects of $\mathrm{Pb}$ occur at lower threshold levels than in adults (Air Quality Guidelines for Europe, 2000).

$\mathrm{Pb}$ has strong effects on haem biosynthesis and erythropoiesis. Essentially, $\mathrm{Pb}$ interferes with the activity of three enzymes: it indirectly stimulates the mitochondrial enzyme delta-aminolaevulinic acid synthetase (ALAS); it directly inhibits the activity of the cytoplasmatic enzyme $\delta$ ALAD; and it interferes with the normal functioning of intra- 
mitochondrial ferrochelatase, which is responsible for the insertion of iron(II) into the protoporphyrin ring (Schwartz et al., 1990). Anemia is a frequent outcome of chronic $\mathrm{Pb}$ intoxication. In young children, $\mathrm{Pb}$ exposure is associated with a decrease in the biosynthesis of the important hormonal metabolite of vitamin D, namely 1,25-dihydroxy-vitamin D (Tandon et al., 2001).

$\mathrm{Pb}$ is linked to encephalopathy in adults and children. The outcome is frequently fatal in children and those who survive, often present irreversible neurological and neuropsychological sequelae (ATSDR, 1999). With regard to the central nervous system (CNS), neurobehavioral functions have been studied in environmentally exposed children. Several studies suggest a drop in IQ of exposed children to inorganic $\mathrm{Pb}$ (Needleman et al., 1982). Some evidence show a correlation between $\mathrm{Pb}$ exposure and cardiovascular effects, including blood pressure (Den Hond et al., 2003).

According to the IARC, evidence of the carcinogenicity of $\mathrm{Pb}$ compounds in humans is inadequate. However, recent papers reported a correlation between environmental $\mathrm{Pb}$ exposure and some types of cancer (Siddiqui et al., 2002). Two studies (Schwartz and Otto, 1987, 1991) showed an approximate hearing loss of $2 \mathrm{~dB}$ with a $\mathrm{Pb}$ concentration range of $70-180 \mu \mathrm{g} . \mathrm{l}^{-1}$ in the blood.

Correlation between blood $\mathrm{Pb}$ levels and autism or other developmental disorders, as suggested by some studies, are inconclusive (Accardo et al., 1988; Eppright et al., 1996; Wakefield, 2002; Edelson, 2004). The epidemiological data examining teratogenesis suggests that the exposure of human males to $\mathrm{Pb}$ may be associated with significant reproductiverelated harm (Lindbohm et al., 1991).

\section{Arsenic}

Arsenic is known since ancient times. Arsenic compounds were mined by the early Chinese, Greek and Egyptian civilizations. Undoubtedly, they discovered its toxic properties early on. Arsenic has many uses such as: in bronzing, wood preservation, pesticides, pyrotechnics, hardening and improving the sphericity of shot, and used in a variety o semiconductor applications (eg.: solar cells, lightemiting diodes, lasers, and integrated circuits) (ATSDR, 2000).

Because of its ubiquity, arsenic is present in biological media of animal and plants, even without any adverse health effect. In blood, total arsenic varies from 1.5 to 2.5 Mg.L-1 (Apostoli, 1999; Hindmarsh and McCurd, 1986).
Concentrations in hair varies from 0.25 to $0.88 \mu$ g.L $\mathrm{L}^{-1}$ (Yamato, 1988), and in urine the average concentrations are between 20 and $50 \mu \mathrm{g} . \mathrm{L}^{-1}$.

Arsenic, despite its poisonous reputation, may be a necessary ultra-trace element for red algae, chickens, rats, goats, and pigs. Its deficiency results in inhibited growth. Arsenic is usually found in the environment combined with other elements as inorganic and organic forms. The organic species are usually less toxic than the inorganic forms. Most cases of human toxicity from arsenic have been associated with exposure to inorganic arsenic. The most common inorganic arsenical in air is arsenic trioxide $\left(\mathrm{As}_{2} \mathrm{O}_{3}\right)$, while a variety of inorganic arsenates $\left(\mathrm{AsO}_{4}{ }^{-3}\right)$ or arsenites $\left(\mathrm{AsO}_{2}\right)$ occur in water, soil, or food. A number of studies have pointed out differences in the relative toxicity of these compounds, with trivalent arsenites tending to be somewhat more toxic than pentavalent arsenates (Maitani et al., 1987; ATSDR, 2000; Dopp et al., 2004).

In general, arsenic species are found in marine foods at concentrations higher than in terrestrial ones. Total arsenic content in seaweed used as human food varies from 3 to $200 \mu \mathrm{g} \cdot \mathrm{g}^{-1}$ and in crustaceans from 10 to $100 \mu \mathrm{g} \cdot \mathrm{g}^{-1}$. In fish, As concentrations vary according to the species but are normally between 5 to $100 \mu \mathrm{g}^{-g^{-1}}$. Values as high as 100 to $250 \mu \mathrm{g} . \mathrm{g}^{-1}$ can be found in species at the top of the food chain (Michel, 1993). It has been demonstrated that even at these high concentrations, arsenic does not cause any damage to health because $80-95 \%$ of As is present as organic species (arsenosugar, arsenolipids, etc).

The most relevant case of arsenic intoxication by food occurred in the western areas of Japan (including Kinki, Chugoku, Shikoku, and Kyushu) in 1955. Arsenic was accidentally mixed into the Morinag's Powdered Milk "MF", produced by the Tokushima plant of the Morinaga Milk Company. As consequence, of the 13,389 newborn babies that ingested the contaminated MF milk, 600 died. While 6,093 suffered health difficulties, 624 were afflicted by severe mental retardation, developmental difficulties, and brain-damage-related paralysis (Ui, 1992).

\section{Health effects of oral chronic exposure to arsenic}

In humans, most cases of toxicity have resulted from accidental, suicidal, homicidal, or medicinal ingestion of arsenic-containing powders or solutions or by consumption of contaminated food or drinking water. In some cases, the chemical form is known, but in many cases (e.g., exposures through drinking water), it is not specified. In these cases, it 
is presumed that the most likely forms are either inorganic arsenate $[\mathrm{As}(+5)]$ or inorganic arsenite $[\mathrm{As}(+3)]$, or a mixture.

Bronchitis and sequelae (bronchiectasis, bronchopneumonia) have been observed during autopsy in some chronic poisoning (inorganic forms) cases (Zaldívar and Guillier, 1977). In general, however, respiratory effects have not been widely associated with repeated oral ingestion of low arsenic doses.

A number of studies in humans indicated that inorganic arsenic ingestion might lead to serious effects on the cardiovascular system. Arsenic has been associated with hypertension (Lee et al., 2003; Yoshida et al., 2004). Anemia and leukopenia can be observed in humans poisoned by inorganic arsenicals at relative high diary intake (Tay and Seah, 1975). Clinical examination often revealed that Cd shows toxicity to the liver (ATSDR, 2000), and these hepatic effects could be secondary to the damage of blood vessels. In the case of organic arsenicals, only at high doses were hepatic damage and/or dysfunction observed (Lee et al., 1995; Shum et al., 1995). Arsenite has a suppressive influence on spermatogenesis and gonadotrophin and testosterone release in rats (Sarkar et al., 2003). Some investigations suggest immunological and thyroid hormone impairment (llen and Rana, 2003). There is correlation between arsenic exposure and diabetes mellitus (type II) (Walton et al., 2004).

Inorganic arsenic ingestion can cause dermal effects (hyperkeratosis formation of hyperkeratotic warts or corns on the palms and soles, hyperpigmentation and hypopigmentation), periorbital swelling, the occurrence of spontaneous abortion and damage the nervous system (ATSDR, 2000). However, arsenical compounds are usually neurotoxic only at high doses (ATSDR, 2000; Yoshida et al., 2004). Investigations about genotoxic effects of ingested inorganic arsenicals suggested deleterious effects, mainly in the p53 gene (Hsu et al., 1999). IARC classifies arsenic as part of the group 1 carcinogens to humans. There is convincing evidence from a large number of epidemiological and laboratorial studies that ingestion of inorganic arsenic significantly increases the risk of developing skin cancer and other internal organ cancers, such as the liver, lung, bladder, kidney, colon and prostate gland (Tchounwou et al., 2003; Rossman et al., 2004). Surprisingly, some studies have noted that arsenic has anti-tumor properties in certain situations (ATSDR, 1999; Jakupec et al., 2004). Furthermore, organic arsenicals might possess weak carcinogenic potential.

\section{Mercury}

$\mathrm{Hg}$ and its compounds are highly toxic, especially methylmercury - a potent neurotoxin. It has caused a significant number of human fatalities in several accidents around the world. Due to its wide dispersion through the atmosphere, $\mathrm{Hg}$ is considered a global pollutant, being deposited even in remote pristine aquatic systems, where it is biomagnified through the food chain (UNEP, 2002).

The relationship between $\mathrm{Hg}$ and mankind goes back to ancient times. It was one of the first chemical elements known by man. The first written reference to $\mathrm{Hg}$ was made by Aristotle around $400 \mathrm{AC}$. He called it "hydraargyrum", silvery water, which became its original name and source for its atomic symbol: $\mathrm{Hg}$. Its alternative name "mercury" probably comes from the Latin verb "merx", which means, "trade", since the Roman god, Hg, was associated with trading. Indeed, Romans used Hg extensively. By $77 \mathrm{AD}$, around $4,500 \mathrm{~kg}$ of $\mathrm{Hg}$ was consumed annually by the Romans (Nriagu, 1979).

$\mathrm{Hg}$ use was initially associated with religious and mystical practices and later with medical and industrial applications. The oldest $\mathrm{Hg}$ sample was found in a ceremonial cup inside an Egyptian tomb, dated $15 \mathrm{AC}$. The biocide properties of $\mathrm{Hg}$ and mercurial compounds were long recognized and used by mankind (e.g. syphilis treatment). While antibiotics replaced most of the medicinal uses of $\mathrm{Hg}$ in the mid-20 $0^{\text {th }}$ century, its close relationship with humans continued through its use in dental amalgams. In the $18^{\text {th }}$ century, $\mathrm{Hg}$ was used to recover silver from mines all over the American continent by the Spanish conquerors. However, it was with the invention of instruments of measurement (e.g. thermometers, barometers, etc.) and the development of large-scale industrial processes (e.g. chlor-alkali plants and PVC production) that $\mathrm{Hg}$ usage and release into the environment became significant. The highly diverse uses of $\mathrm{Hg}$ are due to its unique physicochemical properties (e.g. liquid form at room temperature, uniform volume expansion, high surface tension, high vapor pressure with low water solubility, high redox potential, low electrical resistivity, capacity of forming amalgams with several metals, etc.) (Nriagu, 1979; UNEP, 2002)

$\mathrm{Hg}$ occurs in nature in several different forms. The most common forms of $\mathrm{Hg}$ in the environment are: metallic or elemental $\mathrm{Hg}$, mercuric sulfide, mercuric chloride and methylmercury. Minerals of $\mathrm{Hg}$ occur in nature mostly as a variety of sulfide minerals (i.e. cinnabar, metacinnabar and hypercinnabar), from which most $\mathrm{Hg}$ is mined, but it also occurs in the elemental form. However, $\mathrm{Hg}$ can be present in 
the environment as several different species simultaneously, in distinct physical and chemical states (i.e. solid, liquid and gaseous forms; ionic, elemental and complexed/adsorbed species). In general, we can divide $\mathrm{Hg}$ compounds into three main groups: "volatile" species (i.e. $\mathrm{Hg}^{0},\left(\mathrm{CH}_{3}\right)_{2} \mathrm{Hg}$, etc.), "reactive" (i.e. $\mathrm{HgCl}_{2}, \mathrm{Hg}^{+2}$, etc.) and "non-reactive" species (i.e. $\mathrm{HgS}_{(\mathrm{s})}$ and other $\mathrm{Hg}$ sulfides). $\mathrm{Hg}$ has three possible oxidation states $(+2,+1$ and 0$)$, which are readily inter-converted. In fact, several biotic and abiotic processes (e.g. oxidation, reduction, volatilization, methylation, demethylation, etc.) affect the cycling of $\mathrm{Hg}$ through environmental compartments, resulting in a very complex distribution and cycling in nature.

From the effects on human health perspective, however, the most relevant $\mathrm{Hg}$ species are the organomercurials, mainly methylmercury. $\mathrm{Hg}$ (II) forms very stable covalent bonds with carbon, resulting in resistant organometallic species that are liposoluble. Methylmercury is of particular concern not only because it is the most common organomercurial species but also due to its toxicological characteristics. It bioaccumulates in the organisms, having a long biological half-life, and it is efficiently biomagnified through the trophic chain. Furthermore, other $\mathrm{Hg}$ species, with lower toxicity, can be naturally converted to methylmercury, which makes any $\mathrm{Hg}$ release in the environment potentially harmful (Moore and Ramamoorthy, 1984; Morel et al., 1998).

The most famous methylmercury poisoning cases occurred in Minamata and Niigata in Japan in the 1950-1960's where the consumption of methylmercury-contaminated seafood caused the death or incapacitation of thousands of people in these two Japanese cities. This neuropathy was named Minamata disease. Other catastrophic episodes of environmental $\mathrm{Hg}$ contamination occurred in other parts of the world. A particularly tragic incident happened in Iraq in 1972. The consumption of wheat seeds treated with mercurial fungicides by farmers and, later, their disposal in rivers and lakes caused the death of 5,000 to 50,000 people and the permanent disability of more than 100,000 people (possibly more than 500,000) ( Nriagu, 1979; Forstner and Wittmann, 1981).

There is a long history of human contamination by $\mathrm{Hg}$. The first case reported was the poisoning of a miner in the $15^{\text {th }}$ century. The first know case of organomercurial fatal intoxication occurred in a clinical laboratory in Europe in 1865. Hunter et al. (cited in Nriagu, 1979) were the first to describe the symptoms of methylmercury poisoning. Thus, the symptoms were named the Hunter-Russell syndrome.
The different $\mathrm{Hg}$ compounds exhibit very different toxicities; consequently the health effects caused by elemental $\mathrm{Hg}$, inorganic $\mathrm{Hg}$, or organomercurial exposure are completely different. $\mathrm{Hg}$ absorption, metabolism and excretion are, consequently, a function of which $\mathrm{Hg}$ species an individual is exposed to. Also, the sources and routes of exposure to the various $\mathrm{Hg}$ compounds are markedly different. For organomercurials, the major exposure source comes from the diet, especially seafood; the diet can also be the main source of inorganic $\mathrm{Hg}$ exposure for the majority of people; while dental amalgams are the main exposure source to elemental $\mathrm{Hg}$ for the general population and occupational exposure can be significant for some specific workers. Another important issue to be considered, while assessing the health effects of $\mathrm{Hg}$, are the exposure levels. There is an ongoing debate in the scientific community about what $\mathrm{Hg}$ levels cause subtle toxic effects. New data suggest that toxic effects may be taking place at lower $\mathrm{Hg}$ concentrations than recognized before. The consequence of these findings is that a larger part of the global population may be at risk due to $\mathrm{Hg}$ contamination. Finally, besides the factors already mentioned, the extent of $\mathrm{Hg}$ exposure, chronic or acute, also determine the adverse health effects observed and their reversibility (UNEP, 2002).

\section{Health effects of oral chronic exposure to mercury}

Limited information was located regarding respiratory effects in humans after oral exposure to organic Hg. Bronchopneumonia, edematous alveolitis, and the requirement of artificial ventilation were reported (Al-Saleem, 1976; Arito and Takahashi, 1991). It is unclear whether these respiratory effects were the result of direct effects on the respiratory system or were secondary to other effects.

Some studies suggest that even minor increases in methylmercury exposures can cause harmful effects on the cardiovascular system, which may lead to an increased in mortality. In a cohort study, where 1,833 men were observed during a 7 year period, Salonen et al. (cited in UNEP, 2002) found that men with highest dietary $\mathrm{Hg}$ intake had a higher risk of acute myocardial infarction. A later follow up study demonstrated that omega-3 fatty acids had a protective effect against acute coronary disease. This effect was less clear in subjects with high hair $\mathrm{Hg}$, suggesting that $\mathrm{Hg}$ interferes with the protective effect of these fatty acids. Due to the importance of cardiovascular diseases as a cause of death in the world, methylmercury exposures should also be considered in this perspective (UNEP, 2002). Abnormalities in heart rhythms 
(Al-Saleem, 1976), myocarditis, irregular pulse, occasional bradycardia, alterations in electrocardiograms, a decrease in heart chloride (Verschuuren et al., 1976), and an increment in diastolic and systolic blood pressure were observed in humans and animals (Lundgren and Swensson, 1949) after oral $\mathrm{Hg}$ exposure.

Available data on humans describes diarrhea, tenesmus, irritation, blisters in the upper gastrointestinal tract (Jalili and Abbasi, 1961), vomiting (Al-Saleem, 1976), abdominal pain, constipation (Pfab et al., 1996) and gastritis (Castoldi et al., 2003), after oral exposure to organomercurial compounds. In addition, stomatitis is the most common sign of acute high concentration exposure to elemental $\mathrm{Hg}$ vapors (UNEP, 2002).

Renal toxicity has rarely been reported following human exposure to organic forms of $\mathrm{Hg}$. However there are reports of individuals exhibiting glomerulonephritis with proteinuria (glomerular and tubular) and nephritic syndrome, mostly related to occupational exposure to elemental $\mathrm{Hg}$. Work with animals has revealed organic $\mathrm{Hg}$-induced nephrotoxicity in rodents following acute-, intermediate-, and chronic-duration exposure.

Elemental $\mathrm{Hg}$ can also affect kidneys severely. It can be oxidized to $\mathrm{Hg}^{2+}$, which accumulates preferentially in the kidneys. The increased excretion of low molecular-weight proteins demonstrated at low-level exposure, and related to damage to the renal tubes, may constitute the earliest renal effects of $\mathrm{Hg}$ contamination. Finally, renal effects are the endpoint in exposure to inorganic $\mathrm{Hg}$. Even when these effects can be overcome, they may still be relevant because the exposure of the general population is likely to be continuous (UNEP, 2002).

Among the adverse health effects caused by $\mathrm{Hg}$, the neurological effects are the most studied. Methylmercury is a well-documented potent neuro-toxin to humans and to several species of experimental animals following acute, intermediate, and chronic oral exposure. Methylmercury in our food is promptly absorbed in the gastrointestinal track, immediately entering the blood stream. The severe damage of the central nervous system (CNS) caused by methylmercury and also elemental $\mathrm{Hg}$ exposure is due to their ability to cross the blood-brain barrier. Actually, the nervous system is the main target tissue for methylmercury causing several effects and symptoms (UNEP, 2002).

There are several key neurological symptoms of highdose exposure to methylmercury in adults. Since there is no specific medical test for the diagnosis of Minamata disease, a combination of these characteristic symptoms are used to identify cases. The major effects that are seen include motor disturbances, such as ataxia and tremors, as well as signs of sensory dysfunction, such as impaired vision. The predominant neuropathological feature is the degenerative changes in the cerebellum, which is likely to be the mechanism involved in many of the motor dysfunctions. The microscopical examination of the brain of patients that died in Minamata, showed entire regions devoid of neurons, granular cells in the cerebellum, Golgi cells and Purkinje cells. The most common clinical symptoms observed in adults in Minamata were paresthesia, ataxia, sensory disturbances, tremors, impairment of hearing and difficulty in walking. Children showed similar symptoms but with a higher incidence and at lower $\mathrm{Hg}$ exposure levels. On the other hand, the predominant symptom in adults in Iraq was paresthesia, which usually occurred after a latent period. Children showed cerebral palsy, altered muscle tone and deep tendon reflex, as well as delayed developmental stages. In humans, disruptions of higher functions have also been noted, as evidenced by depression and irritability (Gochfeld, 2003; Shanker et al., 2003; Costa et al., 2004).

Children are a high susceptibility group because the developing central nervous system is more vulnerable to injury than that of the adult. Both the Japan and Iraq incidents provided large evidence for the higher risks fetuses and children face when exposed to methylmercury. It readily passes the placental barrier affecting the fetuses directly. Thus, unborn and newborn children can be adversely affected, even when the $\mathrm{Hg}$ exposure levels cause minor or no symptoms to the mother (major exposure route to this group). Several epidemiological studies have shown that methylmercury in seafood diets of pregnant women - even at minimal $\mathrm{Hg}$ concentrations (about 1/10 - 1/5 of the observed effect levels on adults) - appears to have subtle, persistent effects on the children's mental development as observed around the start of school age (so-called cognitive deficits). In a study with children from Faroe Islands, where methylmercury is present in the population's diet, prenatal exposure to methylmercury caused neuropsychological deficits at 7 years of age. The brain functions most vulnerable seem to be attention, memory, and language, while motor speed, visiospatial function, and executive function showed a less remarkable decrease compared to increased $\mathrm{Hg}$ exposures. The $\mathrm{Hg}$ concentration in umbilical cord blood was shown to be the best risk indicator for the harmful effects, which did not seem to be significantly affected by the confounding factors examined. Children exposed to high levels of methylmercury 
(i.e. the Iraq poisoning incident) during pregnancy showed cerebral palsy, which may be indistinguishable from the ones caused by other factors. The main clinical picture is microcephaly, hyperreflexia, and gross motor and mental impairment, sometimes associated with blindness or deafness. In less severe cases, the effects may develop only later as psychomotor and mental impairment and persistent pathological reflexes (UNEP, 2002).

Epidemics of human $\mathrm{Hg}$ poisonings have occurred with high incidences of developmental toxicity. These episodes, as well as case reports from isolated incidences of maternal consumption of organic forms of $\mathrm{Hg}$ during pregnancy, have provided evidence that the developing nervous system of the fetus is highly sensitive to $\mathrm{Hg}$ toxicity (Mendola et al., 2002).

Neurodevelopmental effects in children are the most widely accepted non-lethal effect of $\mathrm{Hg}$ contamination. The benchmark dose level (BMD), calculated from the Faroe Islands study, is $58 \mu \mathrm{g} . \mathrm{L}^{-1}$ of total $\mathrm{Hg}$ in umbilical cord blood (or $10 \mu \mathrm{g} . \mathrm{g}^{-1}$ of total $\mathrm{Hg}$ in maternal hair). These tissue levels are the result of an estimated average daily intake of about $1 \mu \mathrm{g}$ of methylmercury per kilogram of body weight per day. This BMD value, whose calculation involved several scientifically-based choices such as an uncertainty factor, the statistic model and the specific effect/ test of effect used, aims to establish a safe exposure level to $\mathrm{Hg}$ for humans. In the Faroe Islands study, developmental delays were significantly associated with the methylmercury exposures. At the low exposure level, a developmental delay of 1-2 months was correlated with every doubling of the prenatal methylmercury exposure level. Individually, these development delays may seem trivial but at a populational level they may have serious consequences. However, in an ongoing prospective study in the Seychelles islands, no association between methylmercury exposure (measured through the $\mathrm{Hg}$ concentration in the hair of pregnant mothers) and developmental effects in their children (up to 5.5 years old) were found (UNEP, 2002).

Several studies reported genotoxic effects in humans after oral exposure to organic Hg (Betti et al., 1993; De Flora et al., 1994; Belletti et al., 2002). Data from some studies give limited support to an association between chromosomal aberrations and $\mathrm{Hg}$ in red blood cells and an increased prevalence of sister chromatid exchange in subjects consuming large amounts of contaminated freshwater or marine biota. However, no increase in the frequency of sister chromatid exchange or numerical chromosomal alterations was observed in a study where individuals ate fish caught from a a methylmercury-contaminated area in Colombia. More recently, a correlation was found between the prevalence of micronuclei in peripheral lymphocytes and blood $\mathrm{Hg}$ concentrations in a population whose main diet was Hg-contaminated seafood (UNEP, 2002).

IARC classifies methylmercury as a possible human carcinogen (group 2B). Some data support the carcinogenic effect of methylmercury (Mitsumori et al., 1990; Dare et al., 2001; Kazantzis, 2002). The methylmercury exposure may be correlated with lung, kidney, and central nervous system tumors (Mitsumori et al., 1990). Among the several studies conducted with Minamata populations regarding cancer risk, one clearly indicated that a higher $\mathrm{Hg}$ exposure increased liver and esophagus cancer mortality compared to controls. Also, an increased risk of chronic liver disease and cirrhosis was observed. Nevertheless, in a cohort study in Sweden with subjects that used organomercurials for seed disinfection, showed no increase in levels of brain cancer (UNEP, 2002).

Several studies showed that a diet with methylmercury chloride caused renal tumors in mice, but not in rats. However, the overall IARC assessment decided that there is sufficient evidence for carcinogenicity of methylmercury in animals and it is possibly carcinogenic to humans (group 2B). On the other hand, the IARC assessment found that elemental $\mathrm{Hg}$ and inorganic $\mathrm{Hg}$ are not classifiable as to their carcinogenicity to humans (group 3) (UNEP, 2002).

Continuous exposure conditions to elemental $\mathrm{Hg}$ can lead to its accumulation in the thyroid. $\mathrm{Hg}$ affects a specific enzyme system at moderate occupational exposure levels (urinary $\mathrm{Hg}$ concentrations of $15-30 \mu \mathrm{g} \cdot \mathrm{g}^{-1}$ creatinine) (UNEP, 2002).

Inorganic $\mathrm{Hg}$ compounds were capable of inducing immune-mediated disease in some strains of mice and rats, although the nature of the response seemed to be dependent on the strain used in the experiments. Some studies with humans occupationally exposed to median levels of elemental $\mathrm{Hg}$ showed alterations in the biochemistry of the immune response system (Pirrone et al., cited in UNEP, 2002).

The acute exposure to elemental $\mathrm{Hg}$ vapors can cause "pink disease" or acrodynia. The distinctive symptoms of this disease are peeling of the palms and soles of the feet, excessive perspiration, itching, rash, joint pain and weakness, elevated blood pressure, and tachycardia. Research with occupationally-exposed individuals suggested that elemental $\mathrm{Hg}$ might affect human reproduction by increasing spontaneous abortions and congenital anomalies, 
and reducing fertility in women. On the other hand, the reproductive effects of elemental $\mathrm{Hg}$ exposure in men are not conclusive (UNEP, 2002).

Several factors may influence the adverse effects of $\mathrm{Hg}$ exposure, either reducing or enhancing them. Limited evidence advocates that nutritional status (e.g. mal-nourishment) and dietary interactions (i.e. possibly protective: selenium, vitamin E, omega 3; possibly enhancers of toxicity: alcohol) can alter $\mathrm{Hg}$ toxicity or affect the endpoints measured in studies. Furthermore, other pollutants in the diet (e.g. PCBs) can interact with $\mathrm{Hg}$, triggering synergistic effects and confounding the research results. This can be particularly relevant when assessing more subtle chronic effects (UNEP, 2002).

\section{REFERENCES}

Accardo P, Whitman B, Caul J, Rolfe U (1988) Autism and plumbism. A possible association. Clin. Pediatr. 27:4144.

Agency for Toxic Substances and Disease Registry - ATSDR (1999) Toxicological profile for lead. Atlanta, GA: U.S. Department of Health and Human Services, Public Health Service.

Agency for Toxic Substances and Disease Registry - ATSDR (2000). Toxicological profile for arsenic. Atlanta, GA: U.S. Department of Health and Human Services, Public Health Service.

Air Quality Guidelines for Europe - (2000) WHO Regional Publications, European Series, No. 912 을 edition. 288 pp

Alloway BJ (1995) Heavy Metals in Soils. Blackie Academic Press, New York.

Al-Saleem T (1976) Clinical Committee on Mercury Poisoning. Levels of mercury and pathologic changes in patients with organomercury poisoning. Bull. World Health Organ. 53(suppl):99-104.

Apostoli P (2002) Element in environmental and occupational medicine. J. Chromatogr. B. 778:63-97

Apostoli P (1999) The role of element speciation in environmental and occupational medicine, Fresenius J. Anal. Chem. 363:499-504

Arito H,Takahashi M (1991) Effect of methylmercury on sleep patterns in the rat. In: Suzuki T, Imura N, Clarkson TW (eds), Advances in Mercury Toxicology, pp.381-394. Plenum Press, New York.

Belletti S, Orlandini G, Vettori MV, Mutti A, Uggeri J, Scandroglio R, Alinovi R, Gatti R (2002) Time course assessment of methylmercury effects on C6 glioma cells: submicromolar concentrations induce oxidative DNA damage and apoptosis. J. Neurosci. Res. 70:703-11.

Bellinger D, Bolger M, Goyer R, Barraj L, Baines J. (Served on July 2004) - WHO food additives series 46: cadmium IPCS - INCHEM. http://www.inchem.org/documents/jecfa/ jecmono/v46je11.htm\#_46111000
Betti C, Barale R, Pool-Zobel BL (1993) Comparative studies on cytotoxic and genotoxic effects of two organic mercury compounds in lymphocytes and gastric mucosa cells of SpragueDawley rats. Environ. Mol. Mutagen. 22:172-80.

Bonnell JA, Ross JH, King E (1960) Renal lesions in experimental cadmium poisoning. Br. J. Ind. Med. 17:69-80.

Bressler JP, Olivi L, Cheong JH, Kim Y, Bannon D (2004) Divalent metal transporter 1 in lead and cadmium transport, Ann. N.Y. Acad. Sci. 1012:142-152.

Calabrese EJ, Baldwin LA (2004) Chemotherapeutics and hormesis. Crit. Rev. Toxicol. 33:215-304.

Castoldi AF, Coccini T, Manzo L (2003) Neurotoxic and molecular effects of methylmercury in humans. Rev. Environ. Health 18:19-31.

Costa LG, Aschner M, Vitalone A, Syversen T, Soldin OP (2004) Developmental neuropathology of environmental agents. Annu. Rev. Pharmacol. Toxicol. 44:87-110.

Dare E, Li W, Zhivotovsky B, Yuan X, Ceccatelli S (2001) Methylmercury and $\mathrm{H}(2) \mathrm{O}(2)$ provoke lysosomal damage in human astrocytoma D384 cells followed by apoptosis. Free Rad. Biol. Med. 30:1347-56.

De Flora S, Bennicelli C, Bagnasco M (1994) Genotoxicity of mercury compounds. A review. Mutat. Res. 317:57-79.

Den Hond E, Nawrot T, Staessen JA (2003) Hypertension caused by low-level lead exposure: myth or fact? J. Cardiov. Risk 1:87-97.

Dopp E, Hartmann LM, Florea AM, Rettenmeier AW, Hirner AV (2004) Environmental distribution, analysis, and toxicity of rganometal(loid) compounds. Crit. Rev. Toxicol. 34:301-33.

Dorea JG (2004) Vegetarian diets and exposure to organochlorine pollutants, lead, and mercury. Am. J. Clin. Nutr. 80:237-8

Edelson SM (Served on July 2004) Overview of Autism. Center for the Study of Autism, Salem, Oregon. http:// www.autism.org/overview.html.

Eppright TD, Sanfacon JA, Horwitz EA (1996) Attention deficit hyperactivity disorder, infantile autism, and elevated blood-lead: a possible relationship. Mol. Med. 93:136-8.

Forstner U, Wittmann GT (1981) Metal pollution in the aquatic environment. Springer-Verlag, Heidelberg.

FSIS 48/04 (2000) Total diet study of 12 elements - Al, As, Cd, $\mathrm{Cr}, \mathrm{Cu}, \mathrm{Pb}, \mathrm{Mn}, \mathrm{Hg}, \mathrm{Ni}$, Se, Sn and $\mathrm{Zn}$, Food survey information sheets - www.food.gov.uk/science /survellance.

Gochfeld M (2003) Cases of mercury exposure, bioavailability, and absorption. Ecotoxicol. Environ. Saf. 56:174-179.

Hazell T (1985) Minerals in food: dietary sources, chemical forms, interactions, bioavailability. World Rev. Nutr. Diet 46:1-123.

Henson MC, Chedrese PJ (2004) Endocrine disruption by cadmium, a common environmental toxicant with paradoxical effects on reproduction. Exp. Biol. Med. 229:383-392.

Herrman JL, Younes M (1999) Background to the ADI/TDI/ PTWI, Regul. Toxicol. Parmacol. 30:S109-113.

Hindmarsh JT, McCurd RF (1986) Clinical and environmental aspects of arsenic toxicity, Crit. Rev. Clin. Lab. Sci. 23: 315-347. 
Hsu C-H, Yang S-A, Wang J-Y, Yu HS, Lin SR (1999) Mutational spectrum of $\mathrm{p} 53$ gene in arsenic-related skin cancers from the Blackfoot disease endemic area of Taiwan. Br. J. Cancer 80:1080-1086.

Hurrell RF (2001) Influence of vegetable protein sources on trace element and mineral bioavailability, paper from the Nutrient composition for fortified complementary foods. PAHO, Washington.

IARC - The International Agency for Research on Cancer (served on July 2004) - Overall Evaluations of Carcinogenicity to Humans - http://monographs.iarc.fr/monoeval/ crthgr01.html.

IEH Report on Factors affecting the absorption of toxic metals from diet (1998) www.le.ac.uk/ieh/pdf/ExsumR8.pdf .

IPCS - International Programme on Chemical Safety - (1992) Cadmium. Environmental Health Criteria 134. Geneva. World Health Organization.

Jakupec MA, Keppler BK (2004) Gallium and other main group metal compounds as antitumor agents. Met. Ions Biol. Syst. 42:425-462.

Jalili HA, Abbasi AH (1961) Poisoning by ethyl mercury toluene sulphonanilide. Br. J. Ind. Med. 18:303-308.

Jarup L (2003) Hazards of heavy metal contamination. Br. Med. Bull. 68:167-182.

Kaste JM, Friedland AJ, Sturup S (2003) Using stable and radioactive isotopes to trace atmospherically deposited $\mathrm{Pb}$ in montane forest soils. Environ. Sci. Technol. 37:35603567.

Kazantzis G (2002) Mercury exposure and early effects: an overview. Med. Lav. 93:139-147.

Kroes R, Kozianowski G (2002) Threshold of toxicological concern in food safety assessment. Toxicol. Lett. 127:43-46.

Larsen JC, Richold M (1993) Report of workshop on the significance of excursions of intake above the ADI. Regul. Toxicol. Pharmacol. 30:S2-12.

Lee DC, Roberts JR, Kelly JJ, Fishman SM (1995) Wholebowel irrigation as an adjunct in the treatment of radiopaque arsenic [letter]. Am. J. Emerg. Med. 13:244-245.

Lee MY, Jung BI, Chung SM, Bae ON, Lee JY, Park JD, Yang JS, Lee H, Chung JH (2003) Arsenic-induced dysfunction in relaxation of blood vessels. Environ. Health Perspect. 111:513-517.

Lindbohm ML, Sallmen M, Anttila A, Taskinen H, Hemminki K (1991) Paternal occupational lead exposure and spontaneous abortion. Scand. J. Work Environ. Health. 17:95-103.

Llen T, Rana SV (2003) Oxidative stress by inorganic arsenic: modulation by thyroid hormones in rat. Comp. Biochem. Physiol. C Toxicol. Pharmacol. 135:157-162.

Lundgren KD, Swensson A (1949) Occupational poisoning by alkyl mercury compounds. J. Indust. Hyg. Toxicol. 31: 190-200.

Maitani T, Saito N, Abe M, Uchiyama S, Saito Y (1987) Chemical form-dependent induction of hepatic zinc-thionein by arsenic administration and effect of co-administered selenium in mice. Toxicol. Lett. 39:63-70.

Mendola P, Selevan SG, Gutter S, Rice D (2002) Environmental factors associated with a spectrum of neurodevelopmental deficits. Ment. Retard. Dev. Disabil. Res. Rev. 8:188-197.
Michel P (1993) Arsenic in marine medium; biochemistry and ecotoxicology, Pepères. Ocean n 4. Ed Ifremer, Paris.

Michalke B (2003) Element speciation definitions, analytical methodology, and some examples. Ecotoxicol. Environ. Saf. 56:122-139.

Miller JR, Hudson-Edwards KA, Lechler PJ, Preston D, Macklin MG (2004) Heavy metal contamination of water, soil and produce within riverine communities of the Rio Pilcomayo basin, Bolivia. Sci. Total Environ. 320:189-209.

Millis PR, Ramsey MH, John EA (2004) Heterogeneity of cadmium concentration in soil as a source of uncertainty in plant uptake and its implications for human health risk assessment. Sci. Total Environ. 326:49-53.

Mitsumori K, Hirano M, Ueda H, Maita K, Shirasu Y (1990) Chronic toxicity and carcinogenicity of methylmercury chloride in B6C3F1 mice. Fundam. Appl. Toxicol. 14: 179-190.

Moore JW, Ramamoorthy S (1984). Mercury. Heavy Metals in Natural Waters, Springer-Verlag. VII: 125-160.

Moreira FR, Moreira JC (2004) Effects of lead exposure on the human body and health implications Rev. Panam. Salud Publica 15:119-129.

Morel FMM, Kraepiel AML, Amyot M (1998). The chemical cycle and bioaccumulation of mercury. Annu. Rev. Ecol. Syst. 29: 543-566.

Needleman H, Leviton A, Bellinger D (1982) Lead-associated intellectual deficit (letter). N. Engl. J. Med. 306:367

Nriagu JO (1979) Production and Uses of Mercury. The Biogeochemistry of mercury in the Environment: Topics in Environmental Health. Amsterdam, Elsevier/North Holland Biomedical Press.

Olsson IM, Bensryd I, Lundh T, Ottosson H, Skerfving S, Oskarsson (2002) Cadmium in blood and urine - impact of sex, age, dietary intake, iron status, and former smokingassociation with renal effects. Environ. Health Perspect. 110:1185-1190.

Oudeh M, Khan M, Scullion J (2002) Plant accumulation of potentially toxic elements in sewage sludge as affected by soil organic matter level and mycorrhizal fungi. Environ. Pollut. 116:293-300.

Peraza MA, Ayala-Fierro F, Barber DS, Casarez E, Rael LT (1998) Effects of micronutrients in metal toxicity. Environ. Health Perspect. 106:203-216.

Pfab R, Muckter H, Roider G, Zilker T (1996) Clinical course of severe poisoning with thiomersal. J. Toxicol. Clin. Toxicol. 34:453-460.

Pirkle JL, Kaufmann RB, Brody DJ, Hickman T, Gunter EW, Paschal DC (1998) Exposure of the U.S. population to lead, 1991-1994. Environ. Health Perspect. 106:745-750.

Pizent A, Jurasovie J, Telisman S (2001) Blood pressure in relation to dietary calcium intake, alcohol consumption, blood lead, and blood cadmium in female nonsmokers. J. Trace Elem. Med. Biol. 15:123-130.

Powell JJ, Jugdaoshingh R, Thompson RPH (1999) Regulation of mineral absorption in the grastrointestinal tract. Proc. Nutr. Soc. 58:147-153.

Reesal MR, Dufresne RM, Corbet K (1987) Adverse health effects from industrial and environmental cadmium. AOM Newsletter Vol 5. 
Renwick AG, Walker R, (1993) An analysis of the risk of exceeding the acceptable or tolerable daily intake. Regul. Toxicol. Pharmacol. 18:463-480.

Rossman TG, Uddin AN, Burns FJ (2004) Evidence that arsenite acts as a cocarcinogen in skin cancer. Toxicol. Appl. Pharmacol. 198:394-404.

Santos EE, Lauria DC, Porto da Silveira CL (2004), Assessment of daily intake of trace elements due to consumption of foodstuffs by adult inhabitants of Rio de Janeiro city, Sci. Total Environ. 327:69-79.

Sarkar M, Chaudhuri GR, Chattopadhyay A, Biswas NM (2003) Effect of sodium arsenite on spermatogenesis, plasma gonadotrophins and testosterone in rats. Asian J. Androl. 5:27-31.

Satarug S, Ujjin P, Vanavanitkun Y, Baker JR, Moore MR (2004). Influence of body iron store status and cigarette smoking on cadmium body burden of healthy Thai women and men. Toxicol. Lett. 148:177-185.

Satarug S, Moore MR (2004) Adverse health effects of chronic exposure to low-level cadmium in foodstuffs and cigarette smoke. Environ. Health Perspect. 112:1099-103.

Schoof RA, Yost LJ, Eickhoff J, Crecelius EA, Cragin DW, Meacher DM, Menzel DB (1999) A market basket survey of inorganic arsenic in food. Food Chem. Toxicol. 37:839846.

Schoof RA (2003a) Guide for Incorporating Bioavailability Adjustments into Human Health and Ecological Risk Assessments Part 1: Overview of Metals Bioavailability, Tri-Service Ecological Risk Assessment, http:// enviro.nfesc.navy.new/erb/erb_a/support/wrk_grp/bio_a/ dobioa-guide-part1.pdf.

Schoof RA (2003b) Guide for Incorporating Bioavailability Adjustments into Human Health and Ecological Risk Assessments Part 2: Technical Background Document for Assessing Metals Bioavailability, Tri-Service Ecological Risk Assessment, http://enviro.nfesc.navy.new/erb/erb_a/ support/wrk_grp/bio_a/dobioa-guide-part2.pdf.

Schwartz J, Otto DA (1987) Blood lead, hearing thresholds and neurobehavioral development in children and youth. Arch. Environ. Health 42:153-160.

Schwartz J, Otto DA (1991) Lead and minor hearing impairment. Arch. Environ. Health 46:300-305.

Schwartz J, Landrigan PJ, Baker EL Jr, Orenstein WA, von Lindern IH (1990). Lead-induced anemia: dose-response relationships and evidence for a threshold. Am. J. Public. Health 80:165-168.

Shanker G, Syversen T, Aschner M (2003) Astrocyte-mediated methylmercury neurotoxicity. Biol. Trace Elem. Res. 95:1-10.

Shum S, Whitehead J, Vaughn L, Shum S, Hale T (1995) Chelation of organoarsenate with dimercaptosuccinic acid. Vet. Hum. Toxicol. 37:239-242.

Siddiqui MK, Srivastava S, Mehrotra PK (2002) Environmental exposure to lead as a risk for prostate cancer. Biomed. Environ. Sci. 15:298-305.

Smolders E (2001) Cadmium uptake by plants. Int. J. Occup. Med. Environ. Health. 14:177-83.
Speijers G (1999) Precision of estimates of an ADI (or TDI or PTWI), Regul. Toxicol. Pharmacol. 30:S87-93

Takebayashi S, Jimi S, Segawa M, Takaki A (2003) Mitochondrial DNA deletion of proximal tubules is the result of itaiitai disease. Clin. Exp. Nephrol. 7:18-26

Tallkvist J, Bowlus CL, Lonnerdal B (2001) DMT1 gene expression and cadmium absorption in human absorptive enterocytes. Toxicol. Lett. 122:171-177.

Tandon SK, Chatterjee M, Bhargava A, Shukla V, Bihari V (2001) Lead poisoning in Indian silver refiners. Sci. Total Environ. 281:177-82.

Tay CH, Seah CS (1975) Arsenic poisoning from anti-asthmatic herbal preparations. Med. J. Aust. 2:424-428.

Tchounwou PB, Patlolla AK, Centeno JA (2003) Carcinogenic and systemic health effects associated with arsenic exposure - a critical review. Toxicol. Pathol. 31:575-88.

Telisman S, Jurasovic J, Pizent A, Cvitkovic P (2001) Blood pressure in relation to biomarkers of lead, cadmium, copper, zinc, and selenium in men without occupational exposure to metals. Environ. Res. 87:57-68.

Ui J (1992) Industrial pollution in Japan - The United Nations University. Tokyo. Available in http://www.unu.edu/ unupress/unupbooks/uu35ie/uu35ie00.htm.

UNEP (2002). Global mercury assessment, United Nations.

Verschuuren HG, Kroes R, Den Tonkelaar EM, Berkvens JM, Helleman PW, Rauws AG, Schuller PL, Van Esch GJ (1976) Toxicity of methylmercury chloride in rats. III. Long-term toxicity study. Toxicology 6:107-123.

Waalkes MP (2003) Cadmium carcinogenesis. Mutat. Res. 533:107-120.

Wakefield J (2002) New centers to focus on autism and other developmental disorders. Environ. Health Perspect. 110: A20.

Walton FS, Harmon AW, Paul DS, Drobna Z, Patel YM, Styblo M (2004) Inhibition of insulin-dependent glucose uptake by trivalent arsenicals: possible mechanism of arsenic-induced diabetes. Toxicol. Appl. Pharmacol. 198:424-433.

WHO - World Health Organization (1989). Evaluation of Certain Food Additives and Contaminants (Thirty-third Report of the Joint FAO/WHO Expert Committee on Food Additives). WHO Technical Report Series No. 776. World Health Organization, Geneva.

Wu X, Jin T, Wang Z, Ye T, Kong Q, Nordberg G (2001) Urinary calcium as a biomarker of renal dysfunction in a general population exposed to cadmium. J. Occup. Environ. Med. 43:898-904.

Yamato, N. (1988) Concentration and chemical species of As in human urine and hair, Bull. Environ. Contamin. Toxicol. 40:633-640.

Yoshida T, Yamauchi H, Fan Sun G (2004) Chronic health effects in people exposed to arsenic via the drinking water: dose-response relationships in review. Toxicol. Appl. Pharmacol. 198:243-252.

Zaldívar R, Guillier A (1977) Environmental and clinical investigations on endemic chronic arsenic poisoning in infants and children. Zentralbl. Bakteriol. Hyg. 165:226-234. 